\title{
ONS UNIVERSITEIT, 1953.
}

Die Redaksie van Koers het besluit dat elke jaar in die Februarieuitgawe 'n kort oorsig van die werksaamhede en wedervaringe van ons Universiteit opgeneem sal word. Dit is 'n mooi besluit, en ek voldoen graag aan die uitnodiging.

Die jaar 1953 is verby met al sy voorspoed en seëninge maar ook met al sy teenspoed en beproewinge. Vir alles wat ons Universiteit in die jaar ontvang het, die goeie en die sware, moet ons die Here dank, want ons het niks verdien nie.

a. Die Here het tot ons gekom met dood en ernstige siekte. Ons eerste Kanselier, prof. dr. J. D. du Toit, is van ons weggeroep, maar in sy plek is 'n ander man ons gegee, $n l$. die afgetrede Rektor, prof. dr. J. C. van Rooy. 'n Jong hoogleraar, prof. dr. B. J. de Klerk, is ons ontneem, maar ook sy plek is gevul, en wel deur dr. S. P. van der Walt. Ons hooggeagte Rektor moes weens verswakte gesondheid hom aan verdere aktiewe diens onttrek. Ook sy plek is weer gevul. Twee van ons hooglerare, H. G. Schulze en ondergetekende, het die sg. leeftydsgrens van vaste diens bereik, maar albei is weer deur ons Raad benoem. Aan die begin van die jaar is vyf leerstoele gevul: Die nuwe hooglerare is W. N. Coetzee (Latyn), M. C. Roode (Musiek), J. J. Snyman (Opvoedkunde), H. L. Swanepoel (Regte) en B. van Deventer (Ekonomie). Op ons gradedag is een ere-doktoraat en wel aan prof. dr. J. D. du Toit en drie doktorate en wel aan B. R. Buys, Theo. le Roux en J. H. Oosthuizen toegeken. Aan die Voorsitter van die Studenteraad, mnr. V. D'Assonville en aün die hoofdame, mej. Salome Erasmus, is die Raadsmedaljes vir 1953 toegeken. Die nuwe voorsitter van die Studenteraad is die heer Jan Visser.

b. Die jaar 1953 het op suiwer akademiese gebied mooi ontwikkeling grebring. Die Senaat en die Raad het dwarsdeur die jaar besondere aandag geskenk aan die uitbouing van ons aantal fakulteite. Ons Raad het reeds op aambeveling van die Senaat besluit tot die stigting van 'n Fakulteit van Regte. Mct die oog op die stigting is daar reeds drie departemente in die Regte in vooruitsig gestel, aan die hoof waarvan elk 'n hoogleraar sal staan. Ons hoop dat die jaar 1954 die departementele 
erkenning van hierdie fakulteit sal meebring. Die Senaat is ook besig met planne vir die stigting van 'n Fakulteit van Landboukunde. Vir die doel is die samewerking van die plaaslike Landboukollege reeds verkry. 'n Derde, belangrike onderneming is die beplanning van ' $n$ volledige Fakulteit van Musiek, en wel in samewerking met ons eie stigting, die Musiekkonserwatorium. Die Raad het reeds besluit tot die erkenning van twee departemente van Musiek met twee hooglerare. Ons wag nog op erkenning deur die Onderwysdepartement. Die Raad en die Senaat het ook besluit tot die vestiging van 'n departement Frans, en aansoeke word ingewag vir'n senior lektor in die nuwe departement. Verder moet vermeld word die aktitwe ontwikkeling van die studierigtings Bantoetale, Volkekunde en Naturelleadministrasie: op die gebiede het die P.U. vir C.H.O. as 'n Afrikaans-Christelike inrigting ' $n$ besondere, dure roeping. Uitbreiding in sekere ou gevestigde departemente het ook ingetree. Dic volgende vakke het nou ook driejarige kursusse: Staatsleer, Fisiologie en Higiëne, terwyl Kunsgeskiedenis en -waardering 'n tweejarige kursus word. In die hele struktuur van ons Universiteit se wese moet met blydskap en dankbaarheid vermeld word die instelling van twee uiters belangrike, verpligte kursusse: Lewens- en Wêreldbeskouingsleer en Beginsolen Metodeleer. Voortaan sal geen student hierdie inrigting verlaat sonder 'n grondige onderlegging in die beginsel van hierdie Universiteit nie. In die Fakulteit van Natuurwetenskappe is ook kursusse in Statistiek ingestel, wat meegebring het dat in die departement Wiskunde 'n vierde dosent, 'n senior lektor, benoem is vanaf begin 1954 .

Gedurende die jaar 1953 is besluit tot die staking van twee studievakke: Ekonomiese Aardrykskunde en Tik- en Snelskrif as graadvak. Die opleiding in die B.Sc. (Huish.) is gestaak en in die plek daarvan kan waarskynlik 'n B.Sc. (Dieëtkunde). Die Senaat het ook besluit tot die afskaffing van die nonneursgraad in die Fakulteit van Natuurwetenskappe. Wagtende op die besluit van die Parlement gaan ons nog voort met die opleiding van aptekers vir die tksamen van die Aptekerskommissie. Indien die Parlement in 1954 nog besluit om universiteite toe te laat om 'n graad in Farmasie, in te stel, sal ons Universiteit onmiddellik oorgaan tot dic instelling van en opleiding vir die B.Sc. (Farmasie), wat studente tot dic aptekerswese sal toelaat.

In 1953 het ons Universiteit sy vlerke ook in 'n ander opsig uitgeslaan. 'n Begin is gemaak met buitemurse klasse, en wel in die Fakulteit 
van Ekonomiese Wetenskappe. Die begin open belangrike nuwe paaie vir ons.

Gedurende 1953 is ook intensief ingegaan op die hele vraagstuk van toelating en eksaminering van ons studente.. Belangrike veranderings is ingevoer, maar verdere ontwikkeling en proefneming is wenslik en sal ook uitgevoer word.

Ten slotte moet aie aandag gevestig word op die belangrike plek wat navorsing aan ons Universiteit inneem. Een van die sterkste en mees aktiewe Senaatskomitees is die Komitee van Navorsing. Hierdie Komitee beheer nie alleen alle navorsing aan ons Inrigting nie maar dit stel hom opsetlik tot taak om navorsing aan te moedig en te beplan. Navorsing neem hier twee vorme aan: die onafhanklike werk van hooglerare en lektore, en die navorsing deur studente onder leiding van 'n lid van die personeel. In die opsig probeer die P.U. vir C.H.O. om wetenskaplike kennis nie net te onderrig nie maar ook uit te brei. Besondere vermelding verdien in die verband die streekopname van Beheerde Gebied No. 2 (Klerksdorp). Personeellede en studente het ook in 1953 die vrug van hul ondersoek in boek-, brosjure- en artikelvorm gepubliseer. Die lysie van publikasies is aansienlik.

c. Akademiese groei en ontwikkeling vereis geld, geboue en terrein.

Ons Inrigting is ruim voorsien van grondoppervlakte vir ons huidige en toekomstige behoeftes. Maa: wat ons geboue op die terrein betref, is ons minder gelukkig. 'n Universiteit moet oor genoeg doeltreffende moderne geboue beskik. Onder geboue verstaan ons geboue vir administrasie, vir onderwys, vir navorsing, vir huisvesting van studente en so meer. Sinds inkorporasie in $\mathbf{1 9 2 1}$ het ons al heelwat gebou, en tog is daar vandag nog 'n groot tekort.

Dic belangrikste gebou wat ons onmiddellik en dringend nodig het, is nog ' $n$ koshuis vir dames. Ons het reeds twee ruim en geskikte geboue vir die huisvesting van ons jong dogters. Maar die toestroming is so geweldig dat die twee huise nie almal kan neem nie. 'n Tweede gebou wat ons ook dringend nodig het, is ' $n$ gebou vir ons Administrasie. 'n Groeiende universiteit soos die van ons vereis groot bedrywigheid in verband met organisasie en administrasie. Op die oomblik is die Rektor en die Registrateur en hul personeel gehuisves in ondoelmatige kamers en kamertjies. 'n Derde gebou, waarmee reeds begin is, is 'n Studentesaal-dit is ook ' $n$ 
dringende behoefte. In aanbou is reeds 'n Fisika-laboratorium, terwyl die Laboratorium vir Geologie onmiddellik vergroot moet word.

Dit is net die onmiddellike behoeftes. In die verskiet lê daar nog die een gebou op die ander voor.

Maar geboue is duur. Daarvoor is baie geld nodig. En die helfte van die geld moet ons Universiteit self vind.

Volgens die nuwe reëlings in verband met die geldsake van universiteite word onderskei tussen gelde wat van die Staat kom en gelde wat die Universiteit self moet vind.

Die Staat gee aan universiteite vir hul bedryf baie goeie steun. Die Staat subsidieer die inrigtings op die volgende wyse. Die eerste toekenning geskied op grond van die aantal erkende basiese departemente aan alle universiteite. Vir elk daarvan dra die Staat by die volle som van die eindsalaris van 'n professoraat. Die tweede toekenning word genoem die Standaardvoorsiening. Dit is ietwat meer saamgesteld. Volgens sekere wiskundige formules word steun verleen vir: onderrig, administrasie, biblioteek, laboratoria en diverse. Oor die algemeen is die voorsiening ruim en doeltreffend. Dit laat sake glad verloop. 'n Derde toekenning deur die Staat geskied slegs op die grondslag van pond vir pond.

En daar begin die groot taak van elke universiteit. Dit moet eie gelde hê. Die vraag is hoe dit aan die gelde kan kom. . Daar is twee bronne: universiteitsgelde betaalbaar deur sy studente en skenkings deur sy ondersteuners en vriende. Die gelde deur studente inbetaal word aangewend vir die gewone bedryfskoste. Die skenkings deur ondersteuners en vriende vorm die grondslag vir alle uitgawes in verband met uitbreiding; m.a.w. alle kapitaaluitgawes begin by skenkings. Dit is op die skenkings dat die Staat pond vir pond bydra. Die gesamentlike bedrag word in die reël aangewend vir die oprigting van geboue.

Die nuwe finansiële reelings bring een belangrike beginsel duidelik na vore: die selfstandigheid van die universiteit. Die Staat gee sy subsidie en laat aan die universiteit groot vryheid in die administrasie. Hoofeis bly dat elke inrigting moet toesien dat sy sake klop. Vir hierdie beginsel is ons as Universiteit vir Christelike onderwys in die besonder dankbaar. Dit stel ons in staat om wat die lopende uitgawes betref, met gerustheid en veiligheid aan te gaan, terwyl ons beginsel ten volle uitgeleef kan word. 
Ten slotte mag net bygevoeg word dat die salarisse van alle personeellede vanaf 1 Januarie 1953 aansienlik verhoog is, sodat ons manne en vroue vrywel onbekommerd oor hul geldsake hulle aan hul werk aan ons Universiteit kan gee.

Vir wat ons in 1953 van die Here ontvang het, mag ons net ons kinderlike dank betuig.

Mag Hy ons in die jaar 1954 weereens Sy genade betoon, sodat ons Universiteit tot die eer van Sy naam sy weg mag gaan!

8 Januarie 1954.

J. CHR. COETZEE. 